\title{
COMUNICAÇÃO
}

\section{ABSENCE OF HYPERSENSITIVITY TO THE NEGATIVE CHRONOTROPIC EFFECT OF ACETYLCHOLINE IN THE ATRIA OF MICE ACUTELY INFECTED WITH TRYPANOSOMA CRUZI, CL STRAIN.}

\author{
Jose Guilherme P. Pires and Fausto E. Lima Pereira
}

Cardiac parasympathetic denervation during the acute phase of Trypanosoma cruzi infection is believed to play an important role in the pathogenesis of Chagas'cardiopathys. As Trypanosoma cruzi infection in mice produces myocarditis with characteristics similar to Chagas 'myocarditis in humans" ${ }^{25}$, this model was chosen to investigate the sensitivity of atrial muscarinic receptors to exogenously administered acetylcholine ( $\mathrm{ACh})$. In a previous study ${ }^{10}$ using atria of mice chronically infected with either a reticulotropic (Y) or a myotropic (CL) strain of Trypanosoma cruzi, it was reported no significant change in the sensitivity to $\mathrm{ACh}$, a result that might be due to reinnervation processes occuring after the acute phase, as shown in rats ${ }^{78}$. So, it was decided to investigate the atrial reactivity to $\mathrm{ACh}$ during the acute phase of Trypanosoma cruzi infection in mice. The CL strain was choses because it induces a more severe myocarditis than the Y strain ${ }^{1}$.

Albino mice weighing 24-32 g were inoculated intraperitonally with 200 trypamastigotes/g of a CL strain of Trypanosoma cruzi.

All infected animals exhibited blood parasites after infection, as determined by means of microscopic examination of a drop of blood 14 days after infection. After 30 days of infection (acute phase) the animals were killed for in vitro recording of the effects of $\mathrm{ACh}$. Age-matched

\footnotetext{
Departments of Physiological Sciences and Pathology, Biomedical Center, Espirito Santo Federal University, Vitória, ES, Brazil. Research partially supported by Fundaçāo Ceciliano Abel de Almeida.

Address for correspondence: Prof. José Guilherme Pinheiro Pires, Dept ${ }^{\circ}$ de Ciências Fisiológicas/CB/UFES. Caixa Postal 780,29001 Vitória, ES, Brasil.

Recebido para publicação em 20/06/91.
}

noninfected mice were used as controls. Atria (left and right) were mounted in a 7 ml-organ bath $\left(32^{\circ} \mathrm{C}\right)$, filled with modified Locke solution (154 $\mathrm{mM} \mathrm{NaCl}, 5.6 \mathrm{mM} \mathrm{KCl}, 2.2 \mathrm{mM} \mathrm{CaCl}, 0.08 \mathrm{mM}$ $\mathrm{NaH}_{2} \mathrm{PO}_{4}, 1.9 \mathrm{mM} \mathrm{NaHCO}$ and $5.5 \mathrm{mM}$ glucose) and bubbled with $\mathrm{O}_{2}$. The atria were attached to a force transducer (Narco F-50) and tension was recorded on a Narco DPM-4B polygraph. An initial tension of $0.1 \mathrm{~g}$ was applied to the tissues. An equilibration period of $40 \mathrm{~min}$ was allowed before experiments were started. Acetylcholine chloride (from Sigma Co.) was added to the organ bath and a dose-response curve produced. The effect or $\mathrm{ACh}$ was expressed as the decrease in beating rate relative to the previous basal value (bpm). Data were expressed as mean \pm S.E.M. and analyzed statistically by the Student's $t$-test, P less than 0.05 being considered significant. After the experiments, the atria were fixed in $10 \%$ formalin and were paraffin embedded for light microscopy.

Histological examination of the atria from infected mice showed multifocal myocarditis with destruction of some cardiac cells and presence of mononuclear exudate. The atrial ganglia observed in each case showed focal inflammatory lesions, with apparent low level of neuronal destruction. Basal atrial rate was similar in both groups: $250 \pm 11$ bpm in chagasic $(n=6)$ and $253 \pm 10 \mathrm{bpm}$ in control $(n=6)$ mice. The dose-response curve to $\mathrm{ACh}$ in atria from infected mice did not significantly differ from the control (Figure 1).

These results demonstrate that acute infection of mice with the CL strain of Trypanosoma cruzi does not induce cholinergic supersensitivity, as it had already been demonstrated during the chronic phase $^{11}$. Chagas 'disease is still considered to be a natural human model of peripheral autonomic denervation $^{10}$, and lesions in cardiac ganglia have 
Comunicação. Pires JGP, Pereira FEL. Absence of hypersensitivity to the negative chronotropic efect of acetylcholine in the atria of mice acutely infected with Trypanosoma cruzi, CL strain. Revista da Sociedade Brasileira de Medicina Tropical 24:259-261, out-dez, 1991

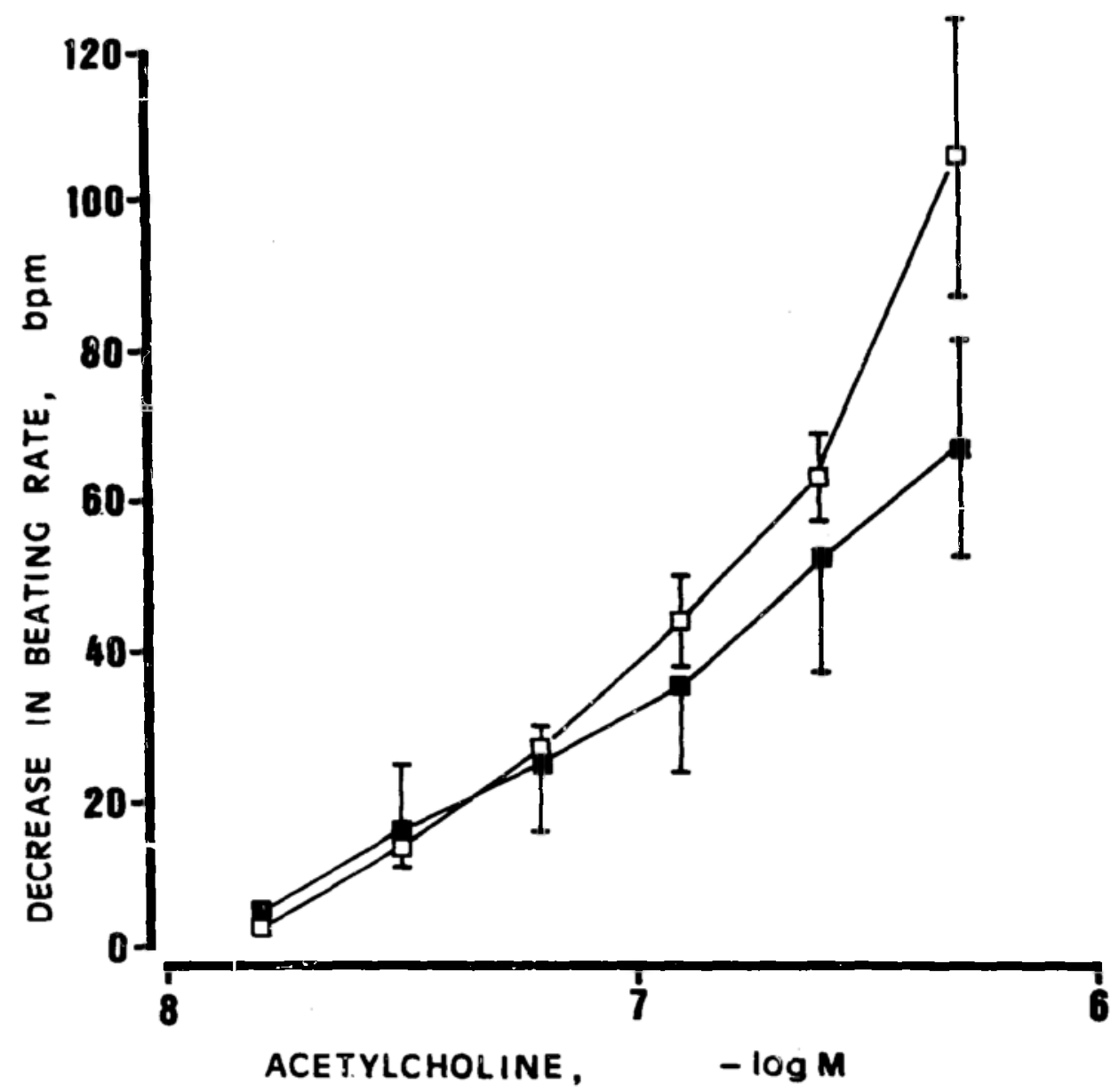

Figure 1 -Dose-response curves for the negative chronotropic effect of acetylcholine on the spontaneous beating of mice atria. Data are reported as means $\pm \operatorname{SEM}$ for control $(-\square-, n=6)$ and infected $(-\mathbf{-}-, n=6)$ animals.

been described in mice acutely infected with Trypanosoma cruzi $i^{2}$. However, the intensity of denervation in atrial ganglia has not been established in mice with acute Trypanosoma cruzi infection. The lesions that we observed in atrial ganglia were focal and do not suggest a severe depletion of nerve cells in those ganglia. Reduction of cardiac neurons has been reported in rats during the acute phase of Trypanosoma cruzi infection'. However, quantitative studies of rats chronically infected with Trypanosoma cruzi showed no significant differences in the number of neurons in respect to age- and sex-matched control rats ${ }^{4}$. Therefore, it is possible that the absence of supersensitivity to ACh that we observed in isolated atria of acutely infected mice would be due to the low intensity of denervation in atrial ganglia.

\section{ACKNOWLEDGMENTS}

We wish to thank Dr. F. Negreiros Gomes and Mr. Nilo Faria for their invaluable help during the preparation of the manuscript. 
Comunicação. Pires JGP, Pereira FEL. Absence of hypersensitivity to the negative chronotropic efect of acetylcholine in the atria of mice acutely infected with Trypanosoma cruzi, CL strain. Revista da Sociedade Brasileira de íedicina Tropical 24:259-261, out-dez, 1991

\section{REFERENCES}

1. Alcântara FG. Sistema neuro-vegetativo do coração na moléstia de Chagas experimental. Revista Goiana de Medicina 7:111-126, 1961.

2. Andrade SG, Andrade ZA. Patologia da doença de Chagas experimental de longa duração. Revista do Instituto de Medicina Tropical de São Paulo 10:180$187,1968$.

3. Andrade ZA, Andrade SG. Patologia. In: Brener Z, Andrade ZA (eds) Trypanosoma cruzie Doença de Chagas. Guanabara Koogan, Rio de Janeiro p.199-248, 1979.

4. Chapadeiro E, Florência RFC, Afonso PC, Beraldo PSS, Jesus PC, Junqueira Jr LS. Neuronal counting and parasympathetic dysfunction in the hearts of chronically Trypanosoma cruzi infected rats. Revista do Instituto de Medicina Tropical de São Paulo 33:337-341, 1991.

5. Koeberle F. Chagas heart disease. Pathology Cardiology 52:82-90, 1968.

6. Laguens RP, Cabeza-Meckert P, Basombrio MA, Chambó PM, Cossio PM, Arana RM, Gelpi R. Infección crónica del ratón con Trypanosoma cruzi. Modelo experimental de enfermedad de Chagas. Medicina 40(Suppl 1):33-39, 1980.

7. Machado ABM, Machado CRS, Gomez MV. Trypanosoma cruzi: acetylcholine content and cholinergic innervation of the heart in rats. Experimental Parasitology 47:107-115, 1979.

8. Machado CRS, Gomez MV, Machado ABM. Changes in choline acetyltrans ferase activity of rat tissues during Chagas'disease. Brazilian Journal of Medical and Biological Research 20:697-702, 1987.

9. Oliveira JSM. A concentração de noradrenalina no miocárdio de ratos sob diversas condições experimentais, com destaque para a infecção pelo T. cruzi. Doctoral Thesis. Faculdade de Medicina de Ribeirão Preto da Universidade de São Paulo, Ribeirão Preto, 1977.

10. Oliveira JSM. A natural human model for intrinsic heart nervous system denervation: Chagas cardiopathy. American Heart Journal 110:1092$1098,1983$.

11. Pereira FEL, Pires JGP. Chronotropic responses to acetylcholine in atria of mice chronically infected with $\mathrm{Y}$ and $\mathrm{CL}$ strains of Trypanosoma cruzi. Brazilian Journal of Medical and Biological Research 21:1019-1021, 1988.

12. Tafuri WL. Pathogenesis of lesions of the autonomic nervous system of the mouse in experimental acute Chagas'disease. American Journal of Tropical Medicine and Hygiene 19:405-417, 1970. 